\title{
Histone H2B Type 1-N
}

National Cancer Institute

\section{Source}

National Cancer Institute. Histone H2B Type 1-N. NCI Thesaurus. Code C162958.

Histone H2B type 1-N (126 aa, 14 kDa) is encoded by the human H2BC15 gene. This protein is involved in the modulation of DNA accessibility. 